\title{
PHENOMENON "LINGUODIDACTIC COMPETENCY" IN THEORETICAL AND PRACTICAL TRAINING OF FUTURE UKRAINIAN AND ENGLISH TEACHERS
}

\author{
Ruskulis L. V., Kordyuk O. M.
}

\section{INTRODUCTION}

The modern educational space requires including highly professional teachers, whose level of training corresponds to European standards and world trends into the learning process of Ukrainian language students. Such provisions are set out in the laws of Ukraine "On Education", "On Higher Education", the National Strategy of Education Development in Ukraine for 2010-2021, the State National Program "Education" ("Ukraine of the $21^{\text {st }}$ Century"), the State Program "Teacher", European recommendations for language education. According to their dominant position, a teacherphilologist is an innovator who has excellent theoretical foundations of discipline, applies his knowledge in practice, conducts constant active scientific research, improves his/her own lingodidactic competency, because "the focus of the educational system on mastering the system of knowledge, which was traditional and motivated a few decades ago, no longer meets the modern social order, which requires educating independent, proactive and responsible members of the society, able to interact effectively in the performance of social, industrial and economic tasks" .

A modern teacher of Ukrainian and English languages must deeply master linguistic theory and linguodidactic principles of language learning, have the appropriate psychological, psychophysiological and practical training. Thus, we are talking about the formation of linguodidactic competency of a graduate of a higher educational institution as the main and fundamental competency, which should be formed in the process of mastering the educational program 014. Secondary education (Ukrainian language and literature. Language and literature English). The formation of linguodidactic competence of a modern graduate is a deep knowledge of approaches, principles, patterns, methods and techniques of teaching that represent a functional part of a language methodology. A student who has mastered the principles of language didactics is a specialist, a highly competitive teacher of Ukrainian and English, who has developed all key competencies (linguistic, professional, didactic, etc).

\footnotetext{
1 Вербицький В. Формування ключових компетентностей учнів - основне завдання навчального закладу. URL: https://lib.iitta.gov.ua/2372/1/Verbytsky.pdf.
} 
The theoretical basis of the study was generalized experience of scientists in the following areas: study of the phenomenon of "linguodidactic competency" (V. Doroz, O. Ishutina, O. Kopus, I. Kucherenko, N. Ostapenko, I. Khyzhniak, etc); L. Boyarova, V. Vynnyk, V. Zhayvoronok, L. Symonenko, L. Poliuga, etc), substantiation of linguodidatic principles in language learning (Z. Bakum, O. Biliaev, N. Golub, T. Donchenko, S. Karaman, O. Kopus, L. Mamchur, V. Melnychaiko, A. Nikitina, S. Omelchuk, N. Ostapenko, M. Pentyliuk, T. Symonenko, I. Khomiak, etc).

The purpose of scientific research is to determine theoretical foundations of forming linguodidactic competency of future Ukrainian language teachers, to clarify the terminology as the basis of linguodidactic competency. To achieve this goal the following tasks are solved: to analyze the system of competencies in training future Ukrainian and English language teachers; to find out the concept of "linguodidactic competency", its structure and components; to analyze the terminological apparatus of linguodidactic competence.

\section{Theoretical investigations of the phenomenon "linguodidactic competency"}

A number of views on the concept of "linguodidactic competency" are presented in the scientific circulation. In particular, N. Ostapenko defines that "linguodidactic competency is a graduate's possession of sets of knowledge, skills, abilities and experience in evaluative attitude to the subject, content and structure of linguistic discipline, use of principles, methods, techniques, means and forms of teaching"2

Having viewed the training of masters $\mathrm{O}$. Kopus represents the following definition of this concept: "a master's possession of set of knowledge, skills, abilities and experience in evaluative attitude to the subject, object, content and structure of linguistic and linguodidactic disciplines, the ability to implement principles, methods, techniques, tools and forms of education, which are an integrated characteristic of the quality of the future master of philology personality" $"$.

G. Tkachenko interprets this concept as a systemic integrity of "interrelated components, quality of a personality and readiness of the future teacher for educational activities at school" $"$.

The opinion of $\mathrm{O}$. Ishutina is appealing to us as she believes that linguistic and methodological competency is "the ability of teachers to productively solve professional problems in the field of language education of students based on the system of knowledge of the Ukrainian language and

${ }^{2}$ Остапенко Н. Теоретичні і методичні засади формування лінгводидактичної компетентності у майбутніх учителів української мови і літератури : автореф. дис. ... докт. пед. наук. Київ, 2010. С. 14. 
teaching methods through awareness of the meta-subject function of the native language and its status as a national and cultural phenomenon; formation of value orientations of a teacher as a person with a high spiritual and moral culture; readiness and desire for professional self-improvement and perception of advanced scientific and methodological experience in the field of teaching the native language" ${ }^{\prime 8}$.

I. Khyzhniak finds out that it is "the ability at a high scientific and methodological level, taking into account psychological and educational specifics, using various forms of organization of the educational process and constantly self-improving, to qualitatively organize the process of formation of language and speech competence", .

As researches show, scientists use both the concepts of "methodological competency" and "linguodidactic competency". In this regard, we pay attention to the researches of O. Igna, who emphasizes that the structure of these concepts is identical, although there are some differences. In the methodological competency of a scientist she sees methodological skills of a teacher, which in complex combines psychological and pedagogical, methodological, subject training, teaching and research activities, i.e. personal and professional characteristics of a teacher. O. Igna represents the following components of methodological competency (based on the training of a foreign language teacher): skills and abilities in the field of technology and methods of teaching foreign languages; mastering methodical linguotheory (terminology); development of communicative competency; the ability to form and develop communicative competency of students; the ability to conduct pedagogical activities; development of critical pedagogical thinking; the ability to apply in practice the obtained theoretical knowledge ${ }^{7}$. The analysis of scientific sources gives grounds to assert that these concepts are identical and complementary, as they have the main content - a linguodidactic training of a student, which covers the mastery of theory and its practical application; formation of his linguistic competence in the process of mastering the educational components provided by the curriculum for bachelors in the specialty 014 . Secondary education (Ukrainian language and literature. Language and literature (English)).

The structure of linguodidactic competency (according to T. Mikhno, I. Khyzhniak) include the following components: basic constructs (linguistic, psychological and pedagogical); basic constructs (linguistic-methodical and informative-communicative); superstructures (diagnostic and acmeological $)^{25}$. Let's focus on their characteristics.

3 Хижняк I.A. Складники інформаційно-комунікаційного конструкта лінгводидактичної компетентності майбутнього вчителя. Вісник Луганського національного університету імені Тараса Шевченка. Педагогічні науки. 2012. № 11. Ч. II. C. 168. 


\section{Basic constructs:}

a) the linguistic component is a perfect mastery of theoretical foundations and acquisition of practical skills in the disciplines of the linguistic cycle, which are provided by the educational and professional training program for students majoring in 014. Secondary education (Ukrainian language and literature. Language and literature (English)): Ukrainian language workshop, Ukrainian language for professional purposes, modern Ukrainian literary languages, Ukrainian dialectology, Old Slavonic language, historical grammar of the Ukrainian language, history of the Ukrainian language, theoretical linguistics, stylistics of the Ukrainian language, theoretical and practical English language course. Students master the necessary volume of information in these disciplines with the obligatory reference to the school course of Ukrainian and English languages, which provides an in-depth analysis of the school program and current textbooks;

b) psychological and pedagogical component is formed by classes in pedagogy, psychology and methods of teaching Ukrainian language and literature and methods of teaching English. The main purpose of pedagogy is to acquaint student with the processes of education and training of an applicant ${ }^{21,22}$. To form linguodidactic competence it is important to master the didactic foundations in pedagogy, which will lay the foundation for the study of linguodidactic problems. In the course of psychology ${ }^{17}$ students learn the peculiarities of the development of general mental processes (thinking, consciousness, speech, imagination, attention, etc.) and the age patterns of personality development and the formation of these mental processes.

\section{Main constructs:}

a) linguistic-methodical is formed when studying methods of teaching Ukrainian language and literature, methods of English language and pedagogy, where there is a comparative analysis of general didactic and specific (actually methodical) approaches, patterns, principles, methods and techniques of language learning; as well as the formation of skills in accordance with students' age characteristics to select didactic material for the lesson of the Ukrainian language ${ }^{4,5,6,7}$;

4 Горошкіна О.М. Лінгводидактичні засади навчання української мови в старших класах природничо-математичного профілю. Луганськ : Альма-матер, 2004. C. 301

${ }^{5}$ Дороз В.Ф. Методика викладання української мови у вищій школі : навчальний посібник. Київ : Центр навчальної літератури, 2008. 176 с.

6 Захлюпана Н.М., Кочан I.M. Словник-довідник 3 методики викладання української мови. Львів : Видавничий центр ЛНУ імені Івана Франка, 2002. 250 с.

7 Копусь О.А. Теоретичні засади формування фахової лінгводидактичної компетентності майбутніх магістрів-філологів у вищому навчальному закладі : монографія. Одеса : Видавництво ТОВ Лерадрук, 2012. С. 15. 
b) information and communication - active introduction into the educational process of innovative teaching aids that "simplify citizens' access to information and data, allow for quick and effective steps to improve production, training, professional and personal development, including education, require appropriate the necessary level of competence in the field of information and communication technologies" communication complex for teachers of Ukrainian language and literature; development of skills to work on platforms YouTube, Facebook, Twitter, Google, Zoom, Moodle; running your own teacher blogs, etc.

\section{Superstructure constructs:}

a) diagnostic, which aims to form linguistic and diagnostic skills of the future teacher, i.e. "sufficient knowledge base and methods of work, so that, working independently, students were prepared to perform full professional functions of a teacher" ${ }^{\text {. }}$. According to scientists the diagnostic skills include: formulating goals and objectives to diagnose the level of knowledge; planning one's own pedagogical activity; creating communicative situations; adaptating existing methods to specific learning objectives; developing methodical materials; determining the causes and degree of deviation from the required level of knowledge; processing and generalizing the received information on the level of knowledge; implementating an individual approach to learning; adequating assessment of one's own diagnostic activity ${ }^{10}$;

b) acmeological component is students' willingness to innovate, design their own pedagogical activities, taking into account their capabilities, because "the school needs a teacher who has reached the acme-tops of pedagogical creativity, capable of innovative transformations and ready to constantly improve their professional level universal network"11. The structure of linguodidactic competence is shown in Figure 1.

L. Sherstyuk emphasizes two components of a student's methodological competency, namely: conducting traditional pedagogical activity; design of innovative pedagogical activity. Particular attention is paid to innovation,

8 Формування інформаційно-комунікаційних компетентностей у контексті євроінтеграційних процесів створення інформаційного освітнього простору : посібник / за заг. ред. В.Ю. Бикова, О.В. Овчарук; НАПН України, Ін-т інформ. технол. і засобів навч. Київ : Атіка, 2014. С. 7.

${ }^{9}$ Хижняк I., Міхно Т. Лінгвометодично-діагностувальні вміння в структурі лінгвометодичної компетентності майбутнього вчителя початкової школи. URL: http://pptma.dn.ua/files/2015/1/PDF_2015_1_Khyzhnyak_Mikhno.pdf.

10 Хижняк I., Міхно Т. Лінгвометодично-діагностувальні вміння в структурі лінгвометодичної компетентності майбутнього вчителя початкової школи. URL: http://pptma.dn.ua/files/2015/1/PDF_2015_1_Khyzhnyak_Mikhno.pdf.

11 Пометун О.І. Дискусія українських педагогів навколо питань запровадження компетентнісного підходу в українській освіті. Компетентнісний підхід у сучасній освіті: світовий досвід та украӥнські перспективи / під заг. ред. О.В. Овчарук. Київ : К. І. С., 2004. С. 68. 
which, in the author's opinion, should include: the ability to design innovations in their own professional activities; psychological and pedagogical characteristics of the class (groups of students), analyzing the circumstances that do not allow the introduction of such innovations; adequate choice of traditional and innovative approaches, patterns, principles, methods, techniques and teaching aids; application of modern methods of diagnosing the level of student' success, as well as providing "creative learning environment based on two principles: openness of the information bank, its availability to all participants in the educational process; individualization, aimed at the development of independence, acquisition of research skills, development of thinking based on cooperation" $"$.

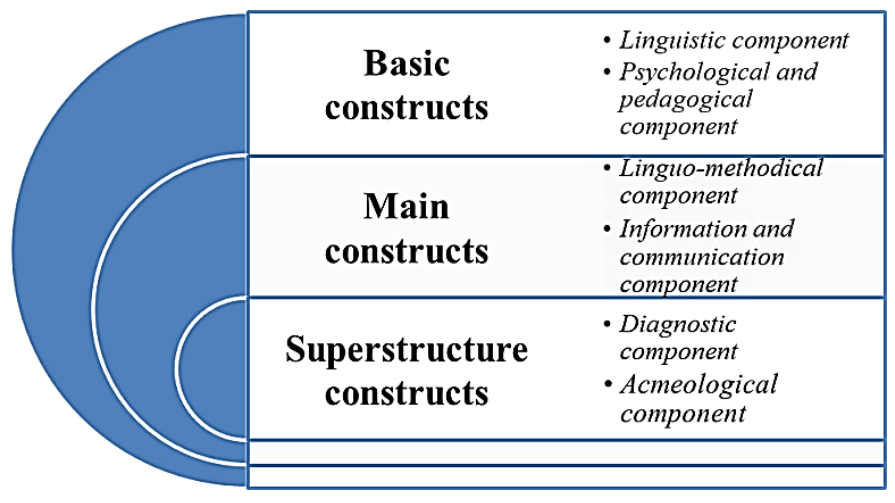

Fig. 1. The structure of linguistic and methodological competency

O. Ishutina represents several other components, which include: informational (assimilation of scientific and methodological material); methodological (tendency to solve methodological problems, awareness of the basics of psychology, pedagogy and language didactics); logical (integrated ability to interpret general trends in the development of linguistics and linguodidactics; personal (development of individual abilities, self-initiative in lectures, practical and seminar classes; observation of the educational process in higher educational institutions); communicative (the use of the language as a means of communication, independent production of texts of different types, genres and styles); motivational (definition of learning goals, identification of professional interest, the desire to improve teaching methods and techniques, information and communication tools; role-playing (master the role of a teacher (mentor,

\footnotetext{
12 Шерстюк Л.В. Сутність та структура методичної компетентності майбутнього викладача-філолога. URL: http://webcache.googleusercontent. com/search.
} 
friend, partner, colleague, head of the language club, etc.)); axiological (culturological) (use of nationally marked texts based on the selection of didactic material), social (teamwork, building subject-subject relations between teacher and student); project (ability to design pedagogical situations, to see different ways to solve them); discursive (the ability to characterize both their own speech and the speech of classmates, teachers in standard learning situations); strategic (orientation in the justified use of linguodidactic categories); diagnostic (the ability to determine the level of a student's preparedness, to choose a system of exercises and tasks for learning Ukrainian and English; to make up tests and conduct test control); linguistic (knowledge of linguistic theory); technological (development of culture and speech technique $)^{8}$.

Organic combination of all structural components is a prerequisite for the formation of a highly professional person who is ready to work in secondary education, has mastered the necessary theoretical scope of linguistic and psychological-pedagogical disciplines, linguodidactic principles of modern Ukrainian and English lessons; has developed language and communication skills and is able to establish contact with students, parents, colleagues; who has research skills.

V. Doroz defines general methodological and special methodological competencies ${ }^{5}$, shown in Figure 2.

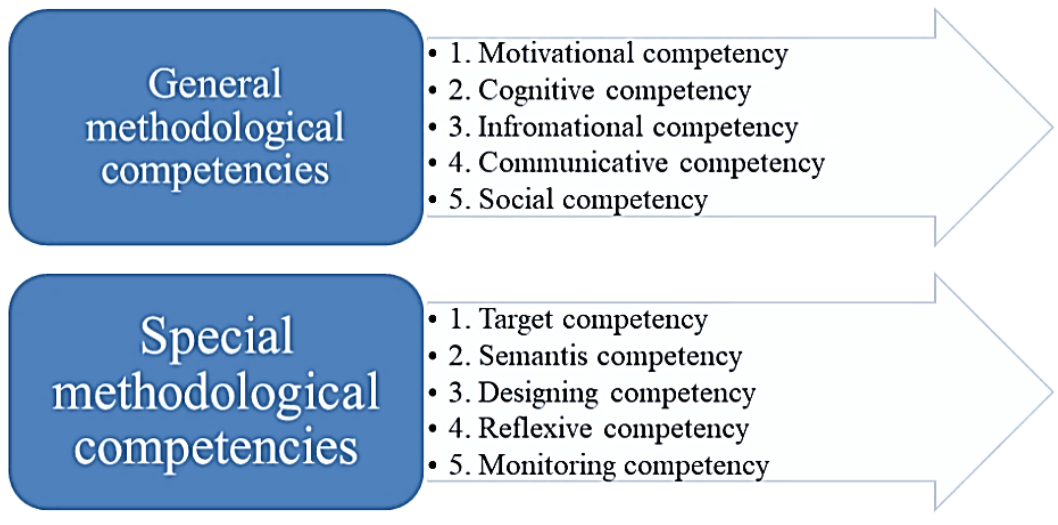

Fig. 2. Interconnection of general methodological
and special methodological competencies

As the figure shows, general methodological and special methodological competencies are in a clear interdependent system. General methodological competencies demonstrate that motivational competency is the formation of a student's interest in the activities of the teacher; cognitive is the desire for continuous self-improvement; informational is the ability of future teachers 
to work with methodological, scientific-methodical and scientific literature, to search for information on the Internet and choose relevant for each case; communicative is the formation of communicative competency of the applicant for higher education, and social is understanding the level of their own methodological growth. Accordingly, special methodological competencies represent the following: target - the ability to determine the purpose of the lesson (class); semantic - to determine the content of the lesson; designing - to determine the features of the educational process; reflexive - selection of effective methodological approaches, methods and techniques of teaching; monitoring - processing of learning outcomes.

The formation of linguodidactic competency of future Ukrainian language teachers in accordance with the criteria determines the readiness of a student for pedagogical activities, which also includes psychological, psychophysiological and practical training of a graduate.

\section{Terminological basis of teacher-vocabulary training as a component of his linguodidactic competency}

Linguodidactic competency of the future teacher of the Ukrainian language is, first of all, mastering professional terminology, "professional vocabulary plays an important role in the development of science and technology and is able to determine the direction for further development of their theoretical positions. As the main means of expression, storage and transmission of special scientific and technical concepts, terminology provides the formulation of problems and the continuity of scientific knowledge" 13 .

A large number of works (L. Boyarova, V. Vynnyk, V. Zhayvoronok, L. Symonenko, L. Poliuga, etc.) are devoted to the problem of forming a terminological system. According to the Great Defining Dictionary of the Ukrainian language, a term is "a word or phrase that means a clearly defined special concept of any field of science, technology, art, social life, etc."14. O. Selivanova notes that a term "is a component of the system of language signs, which serves communication in a particular area together with the commonly used lexicon" ${ }^{15}$. Thus, scholars define a term as a word or phrase used in a particular field.

However, it is not always possible to draw a clear line between terms and commonly used words, and there are several reasons for this:

13 Ткаченко К.Г. Теоретичні основи методичної компетентності майбутніх учителів початкових класів. 2013. С. 5. URL: http://www.sworld.com.ua/index.php/ru/ conference/the-contentof-conferences/archives-of-individual-conferences/ march-2013.

${ }^{14}$ Великий тлумачний словник сучасної української мови / уклад. і голов. ред. В.Т. Бусол. Київ ; Ірпінь : ВТФ «Перун», 2005. С. 1444.

${ }^{15}$ Селіванова О. Лінгвістична енциклопедія. Полтава : Довкілля-К., 2010. С. 736. 
1) terms are components of the explanatory dictionary of the language, already mastered by the system of modern Ukrainian literary language;

2) almost every newly formed word is a product that is projected on a system that has already been processed by scientific knowledge;

3 ) the purpose of non-term words is to clarify scientific knowledge;

4) almost every word is potentially a term;

5) the opposition of the meanings of terms and non-terms in accordance with the accuracy is unfair ${ }^{16}$.

In linguistics, the following types of terms are defined: commonly used, with a wide range of uses; simple and affordable. However, such terms are ambiguous, which does not always mean their correct understanding, raises doubts about the correctness of use. Interdisciplinary terms are specific words that represent science, technology, and professionalism. Narrowly specialized terms are terms that function only in one specific area ${ }^{17}$. The set of terms makes the terminology of the industry. The formation of a student's didactic competence is based on the mastery of intersectoral (pedagogy, psychology, methods of Ukrainian and English) and specialized terminology (formation of linguistic competence at all language levels).

According to the study of M. Lvov ${ }^{18}$, all linguodidactic terms are divided into groups, which we will demonstrate in figure 3.

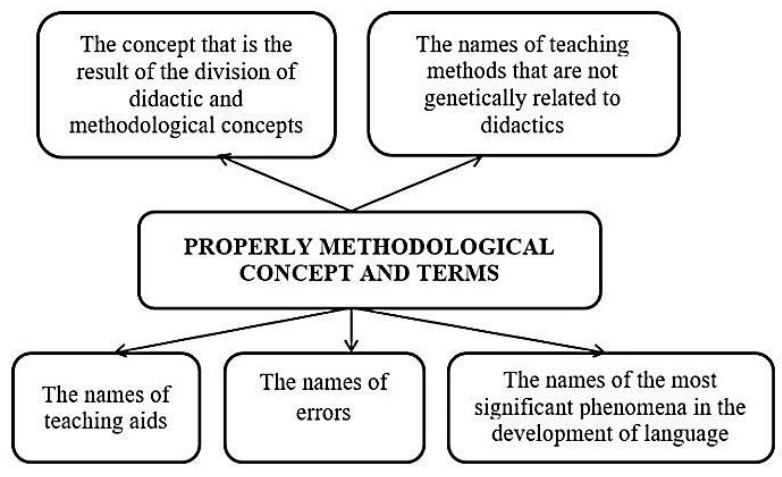

Fig. 3. Linguodidactic terms

16 Котелова Н.3. Семантическая характеристика терминов в словарях. Проблематика определений терминов в словарях разных типов. Ленинград : Наука, 1976. C. 41.

17 Психологічна енциклопедія / авт.-упоряд. О.М. Степанов. Київ : «Академвидав», 2006. 424 с.

18 Львов М.Р. Словарь-справочник по методике русского языка : учебное пособие. Москва : Просвещение, 1988. С. 210. 
The concepts that are the result of the division of didactic and methodological concepts include terms that have formed and are functioning on the border of pedagogy and language didactics (lesson and grammar lesson); names of teaching methods that are not genetically related to didactics are actually linguodidactic principles (dictation, vocabulary work, etc.); the names of teaching aids are also at the junction of linguodidactics and pedagogy (dictionary, information and communication teaching aids, etc.), the names of errors are, in fact, linguodidactical terms (omission, dash, etc.).

The aim of this paper is to characterize the basic concepts that are the result of the division of didactic and methodological concepts, which include approaches to language learning, patterns, principles, methods and techniques of teaching.

The formation of linguodidactic competency is based on taking into account the approaches to language learning, to which scientists refer: competency, activity-oriented, personal, subject-activity, system, activity, polysubjective (dialogical), communicative-activity oriented, etc. The competency approach is related to personality-oriented learning, because it characterizes a student as a subject of educational activity and requires a shift of emphasis on the content of education from an objective to a subjective view of the applicant ${ }^{19}$. The system approach makes it possible to identify integrated connections in the components of the language system, taking into account comprehensive connections, determining which of them are stable and which are variable, which is primary and which is secondary. Such approach clarifies the contribution of individual process components to the development of an individual as a systemic whole ${ }^{20}$. The functionalstylistic approach aims to consider the functioning of language units at all language levels (phonetic, lexicological, grammatical, stylistic) taking into account the type, genre and style of expression. Since the linguistic principles of language learning are based on the study of the word as a central unit of the language system, the functional-stylistic approach is the meaning of a word at the level of the text in a particular style of language. The approach involves the replacement of language units, the definition of speech; improving speech; use of oral speech. The text-centric approach is closely connected with the functional-stylistic approach, which presupposes the understanding of the text as a speech utterance. The approach allows to realize the following tasks of training: to form abilities and skills to express one's own thoughts; to improve the ability to discuss expression patterns; to develop a culture of discussion; follow the rules of speech behavior ${ }^{21}$. Thus,

19 Компетентнісний підхід у сучасній освіті: світовий досвід та українські перспективи / під заг. ред. О.В. Овчарук. Київ : «К.І.С.», 2004. С. 66.

20 Компетентнісний підхід у сучасній освіті: світовий досвід та українські перспективи / під заг. ред. О.В. Овчарук. Київ : «К.І.С.», 2004. С. 66.

21 Пентилюк M.I. Актуальні проблеми сучасної лінгводидактики : збірник статей. Київ : Ленвіт, 2011. С. 100. 
approaches to language learning are the starting points of language didactics, on which the system of regularities, principles, methods and techniques of teaching is based.

Specific patterns of language learning (O. Biliaev, E. Goloborodko, N. Golub, O. Goroshkina, S. Karaman, I. Kucherenko, M. Lvov, M. Pentiliuk, G. Shelekhova, etc.) are represented by two groups: regularities of language learning as "the relationship between linguistic theory and speech practice, the dependence of learning outcomes and language acquisition on the potential of the speech environment created in the learning process and everyday life"; patterns of speech acquisition as "objectively existing connections of the results of speech acquisition from the degree of development of the human speech system, its individual organs" 22 .

An extensive study of the principles of teaching is represented in the works of educators (A. Aleksiuk, S. Vitvytska, N. Volkova, M. Yevtukh, S. Maksymenko, V. Ortynsky, T. Turkot, M. Fitsula, etc.) and language teachers (M. Vashulenko, O. Goroshkina, T. Donchenko, I. Drozdova, S. Karaman, A. Nikitina, M. Pentilyuk, etc.). Principles, based on the laws of learning and performing the functions of systematization, direct the educational process to achieve the pedagogical goal and determine its course. The following principles of teaching are singled out in modern pedagogy: scientificity, systematization, connection of theory with practice; clarity, etc. On the basis of general didactic principles the system of linguodidactic principles of training is developed.

We are impressed by the opinion of T. Donchenko, who clarifies the following specific principles of learning: the principle of studying language units based on text analysis in the unity of content and form; the principle of priority use as didactic material for the occupation of artistic texts, mostly classical; the principle of combining the development of speech and the development of thinking; the principle of conditionality of the main direction in the study of the native language by its communicative function in all its manifestations; the principle of a functional approach to the study of language units; the principle of the relationship between the assimilation of theory and the functioning of language units in speech; functional and stylistic principle of language learning; the principle of awareness of the aesthetic function of the Ukrainian language; the principle of interconnection of individual levels of language; the principle of close interrelation in the acquisition of language and speech knowledge, the formation of educationallanguage, spelling and speech skills ${ }^{23}$.

22 Пентилюк М.I. Актуальні проблеми сучасної лінгводидактики : збірник статей. Київ : Ленвіт, 2011. С. 100.

${ }^{23}$ Донченко Т. До проблеми методів навчання української мови. Украйнська мова і література в школі. № 7. 2005. С. 2-5. 
Scientists (A. Aleksiuk, Y. Babansky, O. Bilyaev, S. Karaman, V. Melnychayko, M. Pentyliuk, A. Peredriy, L. Rozhylo, L. Ruskulis etc.) refer to the linguodidactic system of language teaching methods that contribute to the organization of the educational process and provide successful preparationof a student. The most acceptable classification is the classification according to the method of interaction between a teacher and students (O. Bilyaev, V. Melnychayko, M. Pentyliuk, L. Rozhylo). The development of language didactics requires the use of innovative teaching methods, which include the interactive method ${ }^{13}$, which aims to create comfortable conditions for learning through close cooperation between the teacher and the learner, the teacher as an organizer of the process. Techniques of this method are role and business games, "brainstorming", synonanon method, cluster method, etc. The method of projects which is expedient to use at all lessons on linguistic disciplines is considered effective in training.

The components of teaching methods are techniques. General didactic techniques include: analysis, synthesis, comparison, abstraction, concretization, generalization, induction, deduction and specific, due to the content of the topic, including various types of analysis of phonetic, lexical, morpheme, word-formation, morphological, syntactic and syntactic work ${ }^{24}$.

In general, the system of terms related to the actual methodological concepts and terms will be shown in Figure 4.

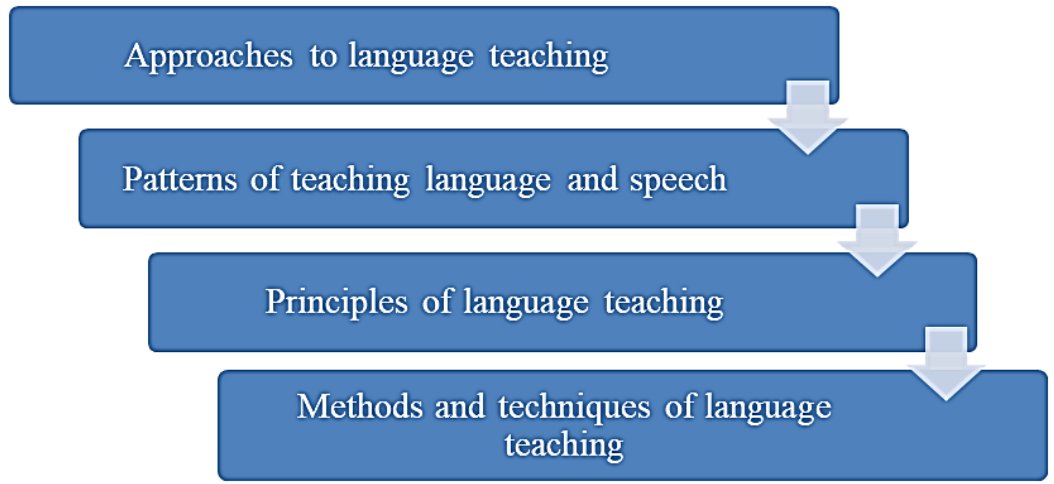

Fig. 4. The system of actual methodological terms and concepts

So, the formation of linguodidactic competency of a student is based on the assimilation of intersectoral and specialized terminology. Based on the classification by division of terms related to didactic and methodological

24 Донченко Т. До проблеми методів навчання української мови. Украӥнська мова і література в школі. № 7. 2005. С. 2-5. 
concepts, we have identified general didactic and specific approaches, patterns, principles, methods and techniques of teaching.

\section{CONCLUSIONS}

The study proved that the problem of training a competent teacher is currently relevant. We conducted a thorough analysis of the concepts of "competency" and "competence" and found that the basis of competency is knowledge, skills, experience, attitude to educational activities of the individual, and components - awareness, ability to successfully implement educational activities, competences, readiness for effective activity and etc. The structure of competency, the functions they perform in the structure of personality are clarified; hierarchy of competencies (key, general and special).

We substantiated that linguodidactic competency is mastering a set of knowledge and skills, a complex of knowledge necessary for teaching; the ability to productively solve professional problems. We have found that the concepts of "methodological competency" and "linguodidactic competency" are identical and complementary. It has been analyzed that the components of linguodidactic competency are basic constructs (linguistic, psychological and pedagogical); main constructs (linguistic-methodical and informationcommunication); superstructure constructs (diagnostic and acmeological). Indicators of linguodidactic competency are determined.

It has been found that the formation of a student's linguodidactic competency is based on the assimilation of intersectoral (pedagogy, psychology, language methodology) and narrowly specialized (formation of linguistic competency at all language levels) terminology. Groups of terms are analyzed; thoroughly characterized terms that are the result of the division of didactic and methodological concepts, which include approaches to language learning, patterns, principles, methods and techniques of teaching.

\section{SUMMARY}

In the course of the research we determined that for a future teacher of Ukrainian and English there is a linguodidactic competency, which we represent as a graduate's possession of sets of knowledge, skills, abilities and experience of attitude to the linguistic discipline; possession of a set of knowledge, skills, abilities and experience of evaluative attitude to linguistic and linguodidactic disciplines, the ability to implement principles, methods, techniques, tools and forms of teaching, interrelated components, personality qualities and student readiness for educational activities at school.

It was substantiated that the structure of linguodidactic competency is represented by the following components: basic constructs (linguistic, psychological-pedagogical); main constructs (linguistic-methodical and information-communication); superstructure constructs (diagnostic and acmeological). 
It was proved that the main indicators of linguodidactic competence are: mastering linguistic theory in classes in linguistic disciplines provided by the educational program of the specialty; definition of traditional and innovative approaches, patterns, principles, methods and techniques of teaching; knowledge of the structure and requirements for the technology of modern language lessons, including non-traditional lessons; establishing intra-level, inter-level and interdisciplinary links in the preparation of language lesson outlines; identification of main activities of students that will effectively promote the learning goal; preparation and use of innovative teaching aids; the ability to find material in the network, analyze it and select relevant; development of high culture of pedagogical activity, covering the developed outlook of a student, his intelligence, ability to think widely, ability to work persistently, high culture of communication.

Linguodidactic competency of the future teacher of Ukrainian and English is mastering professional terminology. The following types of terms are defined in linguistics: commonly used, intersectoral terms and narrowly specialized terms. The set of terms is the terminology of the industry. The formation of linguodidactic competency of a student is based on the assimilation of intersectoral (pedagogy, psychology, language methodology) and specialized terminology (formation of linguistic competency at all language levels).

The concepts that are the result of the division of didactic and methodological concepts include terms that have formed and are functioning on the border of pedagogy and linguodidactics (lesson and grammar lesson); names of teaching methods that are not genetically related to didactics, which are actually linguodidactic principles (dictation, vocabulary work, etc.); the names of teaching aids that are also at the junction of linguodidactics and pedagogy (dictionary, information and communication teaching aids, etc.), the names of errors which are, in fact, linguodidactical terms (omission, dash, etc.). The work characterizes the basic concepts that are the result of the division of didactic and methodological concepts, which include approaches, patterns, principles, methods and techniques of teaching.

\section{REFERENCES}

1. Великий тлумачний словник сучасної української мови / уклад. i голов. ред. В.Т. Бусол. Київ ; Ірпінь: ВТФ «Перун», 2005. 1728 с.

2. Вербицький В. Формування ключових компетентностей учнів основне завдання навчального закладу. URL: https://lib.iitta.gov.ua/ 2372/1/Verbytsky.pdf.

3. Горошкіна О.М. Лінгводидактичні засади навчання української мови в старших класах природничо-математичного профілю. Луганськ : Альма-матер, 2004. С. 301.

4. Донченко Т. До проблеми методів навчання української мови. Українська мова і література в школі. № 7. 2005. С. 2-5. 
5. Дороз В.Ф. Методика викладання української мови у вищій школі : навчальний посібник. Київ : Центр навчальної літератури, 2008. $176 \mathrm{c}$.

6. Захлюпана Н.M., Кочан I.M. Словник-довідник 3 методики викладання української мови. Львів : Видавничий центр ЛНУ імені Івана Франка, 2002. 250 с.

7. Игна О.Н. Структура и содержание методической компетентности учителя иностранного язика. Ярославский педагогический вестник. 2010. № $1 . \quad$ URL: http://vestnik.yspu.org/releases/2010_1g/22.pdf.

8. Ішутіна О. Сутність i структура лінгвометодичної компетентності майбутнього вчителя рідної мови. Науковий вісник Ужггородського начіонального університету. Серія «Педагогіка, соиіальна робота». Вип. 36. С. 67-79.

9. Компетентнісний підхід у сучасній освіті: світовий досвід та українські перспективи / під заг. ред. О.В. Овчарук. Київ : «К.І.С.», 2004. $112 \mathrm{c}$.

10. Копусь О.А. Теоретичні засади формування фахової лінгводидактичної компетентності майбутніх магістрів-філологів у вищому навчальному закладі : монографія. Одеса : Видавництво ТОВ Лерадрук, 2012. 429 с.

11. Котелова Н.3. Семантическая характеристика терминов в словарях. Проблематика определений терминов в словарях разных типов. Ленинград : Наука, 1976. С. 36-42.

12. Львов М.Р. Словарь-справочник по методике русского языка : учебное пособие. Москва : Просвещение, 1988. 240 с.

13. Методика навчання української мови в середніх освітніх закладах: підручник / кол. авт. за ред. М.І. Пентилюк. Київ : Ленвіт, 2004. $400 \mathrm{c}$.

14. Остапенко Н. Теоретичні i методичні засади формування лінгводидактичної компетентності у майбутніх учителів української мови і літератури : автореф. дис. ... докт. пед. наук. Київ, 2010. 37 с.

15. Пентилюк М.I. Актуальні проблеми сучасної лінгводидактики : збірник статей. Київ : Ленвіт, 2011. 256 с.

16. Пометун О.I. Дискусія українських педагогів навколо питань запровадження компетентнісного підходу в українській освіті. Компетентнісний підхід у сучасній освіті: світовий досвід та украйнські перспективи / під заг. ред. О.В. Овчарук. Київ : К. І. С., 2004. $112 \mathrm{c}$.

17. Психологічна енциклопедія / авт.-упор. О.М. Степанов. Київ : «Академвидав», 2006. 424 с.

18. Рускуліс Л.В., Зайцева Т.А. Українська мова (за професійним спрямуванням) : навчальний посібник. Миколаїв : Іліон, 2014. 306 с. 
19. Селіванова О. Лінгвістична енциклопедія. Полтава : Довкілля-К., $2010.844 \mathrm{c}$.

20. Ткаченко К.Г. Теоретичні основи методичної компетентності майбутніх учителів початкових класів. Modern Directions of Theoretical and Applied Researches. 2013. URL: http://www.sworld.com.ua/index.php/ru/conference/the-contentofconferences/archives-of-individual-conferences/ march-2013.

21. Туркот T.I. Педагогіка вищої школи : навчальний посібник. Київ : Кондор, 2001. 628 с.

22. Фіцула М.М. Педагогіка вищої школи : навчальний посібник. Київ : «Академвидав», 2006. 352 с.

23. Формування інформаційно-комунікаційних компетентностей у контексті євроінтеграційних процесів створення інформаційного освітнього простору : посібник / за заг. ред. В.Ю. Бикова, О.В. Овчарук; НАПН України, Ін-т інформ. технол. і засобів навч. Київ : Атіка, 2014. 212 c.

24. Хижняк I.A. Складники інформаційно-комунікаційного конструкта лінгводидактичної компетентності майбутнього вчителя. Вісник Луганського національного університету імені Тараса Шевченка. Педагогічні науки. 2012. № 11. Ч. II. С. 166-172.

25. Хижняк I., Міхно Т. Лінгвометодично-діагностувальні вміння в структурі лінгвометодичної компетентності майбутнього вчителя початкової школи. URL: http://pptma.dn.ua/files/2015/1/PDF_2015_1_ Khyzhnyak_Mikhno.pdf.

26. Шерстюк Л.В. Сутність та структура методичної компетентності майбутнього викладача-філолога. URL: http://webcache.googleusercontent.com/search.

\section{Information about the authors:} Ruskulis L. V.,

Doctor of Education, Associate Professor, Head of the Ukrainian Language and Literature Department V. O. Sukhomlynskyi Mykolaiv National University 24, Nikolska str., Mykolaiv, 54000, Ukraine

Kordyuk O. M., Lecturer at the English Language and Literature Department

V. O. Sukhomlynskyi Mykolaiv National University 24, Nikolska str., Mykolaiv, 54000, Ukraine 